\title{
Discovery of breeding grounds of a Siberian Crane Grus leucogeranus flock that winters in Iran, via satellite telemetry
}

\author{
YUTAKA KANAI, MEENAKSHI NAGENDRAN, MUTSUYUKI UETA, \\ YURI MARKIN, JUHANI RINNE, ALEXANDER G. SOROKIN, HIROYOSHI \\ HIGUCHI and GEORGE W. ARCHIBALD
}

\begin{abstract}
Summary
Siberian Crane Grus leucogeranus occurs only in Asia, and is Critically Endangered. The western population of the species has been almost extirpated, wintering at just two known sites, in Iran and India. To help conserve species that migrate long distances it is essential to have a comprehensive conservation plan that includes identification of migration routes and key resting areas. One Siberian Crane was satellite-tracked from the south Caspian Sea to its breeding grounds in Russia during the spring of 1996. The crane began migration on 6 March, and completed its migration on 1 May. This destination was formerly unknown as a breeding area for the species. During migration, the crane rested primarily at the eastern end of the Volga River delta. This suggests that the delta may be an important resting site for Siberian Crane.
\end{abstract}

\section{Introduction}

Siberian Crane Grus leucogeranus occurs only in Asia, and is Critically Endangered (BirdLife International 2000). There are less than 3,000 in the wild, the majority breeding in Yakutia, eastern Siberia $\left(72^{\circ} \mathrm{N}, 145^{\circ} \mathrm{E}\right)$, and wintering in China along the flood plains of the Yangtze River, including Poyang and other lakes (Meine and Archibald 1996, Kanai et al. 2002).

The western population of Siberian Crane has been almost extirpated and winters at just two known sites, in Iran and India. Since their discovery in 1978, 711 birds have been observed wintering on wetlands near Fereydoon Kenar on the southern shore of the Caspian Sea, Iran. About 200 Siberian Cranes wintered at Keoladeo National Park in India in 1965 (Meine and Archibald 1996), but this figure has since declined and only two arrived during the winter of 2000-2001.

The only known breeding site for the western population is east of the Ural Mountains near the $\mathrm{Ob}$ River, on the Kunovat River basin (around $200 \mathrm{~km}$ south of the Arctic Circle, between $60^{\circ}-65^{\circ} \mathrm{N}$, and $65^{\circ}-75^{\circ} \mathrm{E}$ ). However, the number of cranes recorded here has not corresponded with the numbers recorded on the known wintering sites in India and Iran. The numbers of Siberian Cranes recorded in the Kunovat River basin appear to have declined in line with the numbers wintering at Keoladeo National Park, but the numbers wintering in Iran have remained relatively constant (Meine and Archibald 1996), suggesting they nested separately from those migrating to India. 
To help conserve species that migrate long distances it is essential to have a comprehensive conservation plan that includes identification of migration routes, staging/stopover sites, time spent at the staging/stopover sites, time taken to complete migration, and the threats to the species and its habitat. This information is of added importance for such a rare bird as Siberian Crane. Hunting and loss of wetland habitat, along the entire migration flyway, including their summer and wintering areas, place the species in a perilous position.

To help migratory birds that are endangered, satellite telemetry has been used extensively. During the last decade, researchers have discovered the migration routes, important staging and stopover sites, breeding and wintering areas of several endangered bird species, and habitats have been defined and described using satellite images (Higuchi et al. 1992, 1994, 1996, Kanai et al. 1994, CCRT 1999, Ueta et al. 2000, 2002). Habitat protection has been proposed based on the information obtained from satellite tracking and satellite images. Kanai et al. (2002) successfully tracked Siberian Cranes from their breeding grounds in eastern Siberia to their wintering sites on Poyang Lake, and showed several important resting sites along the migration pathway.

Before May 1996, the location of breeding grounds for the Siberian Cranes wintering in Iran was unknown. This paper describes the successful satellite tracking of one Siberian Crane to its breeding grounds, from the southern boundary of the Caspian Sea during the spring of 1996.

\section{Study area and methods}

The known wintering site of Siberian Cranes in Iran is $1 \mathrm{~km}$ south-east of the town of Ferey-dun-kinar $\left(36.41^{\circ} \mathrm{N}, 52.29^{\circ} \mathrm{E}\right)$, in flooded paddy fields (Sauey 1985). This site is adjacent to the southern coast of the Caspian Sea. The cranes winter in an area that has traditional waterfowl trapping stations called damgahs.

In January 1996 a wild male Siberian Crane from a family group (a pair with one juvenile) was captured at $36.679^{\circ} \mathrm{N}, 52.554^{\circ} \mathrm{E}$, in a trap using a captive Siberian Crane as a decoy. The wild Siberian Crane walked into a cage with a pull door, in an attempt to displace the captive-reared Siberian Crane that had been placed in an enclosure beside the trap. The trap and the live decoy were placed within the feeding territory of the wild Siberian Crane family. The wild crane was fitted with a coloured leg band (white/green/white), a metal leg band (A145920) and a satellite transmitter (platform terminal transmitter or PTT). The PTT (manufactured by Nippon Telephone and Telegraph, weight $80 \mathrm{~g}$, antenna $18 \mathrm{~cm}$ ) was deployed as a backpack unit using Teflon-treated ribbon for harnessing (Nagendran et al. 1994). The duty cycle of the PTT was 6 hours active and 12 hours inactive, and PTT pulse interval was 60 seconds. PTT battery life was expected to be six months.

Argos satellites provided location data. Location class (LC) ranked in order of accuracy, from 3, 2, 1, 0, A, B and Z. Argos (1996) provides one standard deviation accuracy of $>1$, $000 \mathrm{~m}$ for LC $0,350-1,000 \mathrm{~m}$ for LC 1, 150-350 $\mathrm{m}$ for LC 2, and $<150 \mathrm{~m}$ for LC 3 . Location accuracy cannot be estimated for LC A, B, and $\mathrm{Z}$. We utilized LC o-3 when available, but also included other classes except " $\mathrm{Z}$ " when they were close to locations preceding or following better readings and/ or when they were along the logical migration path. 
Table 1. A list of areas visited by a Siberian Crane satellite tracked in 1996. Asterisked $\left(^{*}\right)$ locations were of location class $\mathrm{O}, \mathrm{A}$ or B (see text)

\begin{tabular}{llll}
\hline Latitude & Longitude & $\begin{array}{l}\text { Approximate dates } \\
\text { of stay }\end{array}$ & Kind of use \\
\hline $36.665-36.682^{\circ} \mathrm{N}$ & $52.474-52.545^{\circ} \mathrm{E}$ & Mar. 1 & Wintering \\
$37.192^{\circ} \mathrm{N}$ & $50.388^{\circ} \mathrm{E}^{*}$ & Mar. 6 & Resting \\
$39.620^{\circ} \mathrm{N}$ & $49.333^{\circ} \mathrm{E}^{*}$ & Mar. 10 & Resting \\
$43.797^{\circ} \mathrm{N}$ & $47.261^{\circ} \mathrm{E}$ & Mar. 12 & Resting \\
$45.457^{\circ} \mathrm{N}$ & $46.487^{\circ} \mathrm{E}^{*}$ & Mar. 15 & Resting \\
$45.583^{\circ} \mathrm{N}$ & $47.882^{\circ} \mathrm{E}^{*}$ & Mar. 16 & Resting \\
$46.259-46.300^{\circ} \mathrm{N}$ & $48.913-49.148^{\circ} \mathrm{E}^{*}$ & Mar. 28 - Apr. 12 & Resting \\
$54.795-54.816^{\circ} \mathrm{N}$ & $66.086-66.115^{\circ} \mathrm{E}$ & Apr. 23 - 28 & Resting \\
$58.936-59.095^{\circ} \mathrm{N}$ & $67.306-67.885^{\circ} \mathrm{E}$ & May 1 - Jun. 30 & Breeding \\
\hline
\end{tabular}

\section{Results and discussion}

A total of 95 locations were obtained from January 18 to June 30 . The percentage of good locations (LC 1, 2 and 3) was 51.6\%. Between March 17-27 and April 1322 locations were absent because the transmitter was not functioning well. A wintering site, seven discovered resting sites and a summering site are shown in Table 1. Migration began on 6 March, 1996, some time around mid-morning, and on March 12 the bird had moved to near Kizlyar, $43.797^{\circ} \mathrm{N}, 47.261^{\circ} \mathrm{E}$ (Figure 1 ). On March 15 it moved to the western end of the Volga River delta, around $45.457^{\circ} \mathrm{N}, 46.487^{\circ} \mathrm{E}$. By March 28 the bird had arrived at the eastern end of the Volga delta, near Obzhorovskiy around $46.259^{\circ} \mathrm{N}, 49.056^{\circ} \mathrm{E}$, and remained this location for more than three weeks (Figure 1, Table 1). The delta is the largest inland delta in Europe, and 264 bird species have been recorded in the area. Major problems affecting the delta include upstream water pollution from urban and industrial developments, agricultural pollution from the application of pesticides and fertilizers in the delta itself, and water regulation of the Volga River due to dam constructions (All Russian Research Institute for Nature Protection).

On 23 April the marked Siberian Crane was located at $54.795^{\circ} \mathrm{N}$ and $66.086^{\circ} \mathrm{E}$. The crane stayed at this location until 28 April. On 1 May the crane arrived on its summer range and breeding territory, at $59.038^{\circ} \mathrm{N}$ and $67.679^{\circ} \mathrm{E}$ (Figure 1 , Table 1).

The marked crane took around 56 days to migrate from Iran to Siberia, spending a total of at least 28 days resting at staging sites, primarily at the eastern end of the Volga River delta. Location information also suggested that the crane was resting during the time periods when we were not receiving daily locations. It spent a total of 47 days at the Volga delta. Cramp (1980) stated that Siberian Cranes stay at the Volga delta from late March to mid April, in line with the pattern shown by the satellite tracked bird. Dementiev and Gladkov (Cramp 1980) recorded migratory Siberian Cranes along the rivers Tobol and Emba. These areas are located between satellite-tracked locations presented in this paper. We believe the satellite-tracked Siberian Crane followed a normal spring migration route and normal resting patterns between the southern Caspian Sea and the Ob-Irtysh basin. The marked crane covered a distance of approximately $3,600 \mathrm{~km}$ from the winter site to the breeding grounds, in approximately nine days (Nagendran 1995). 


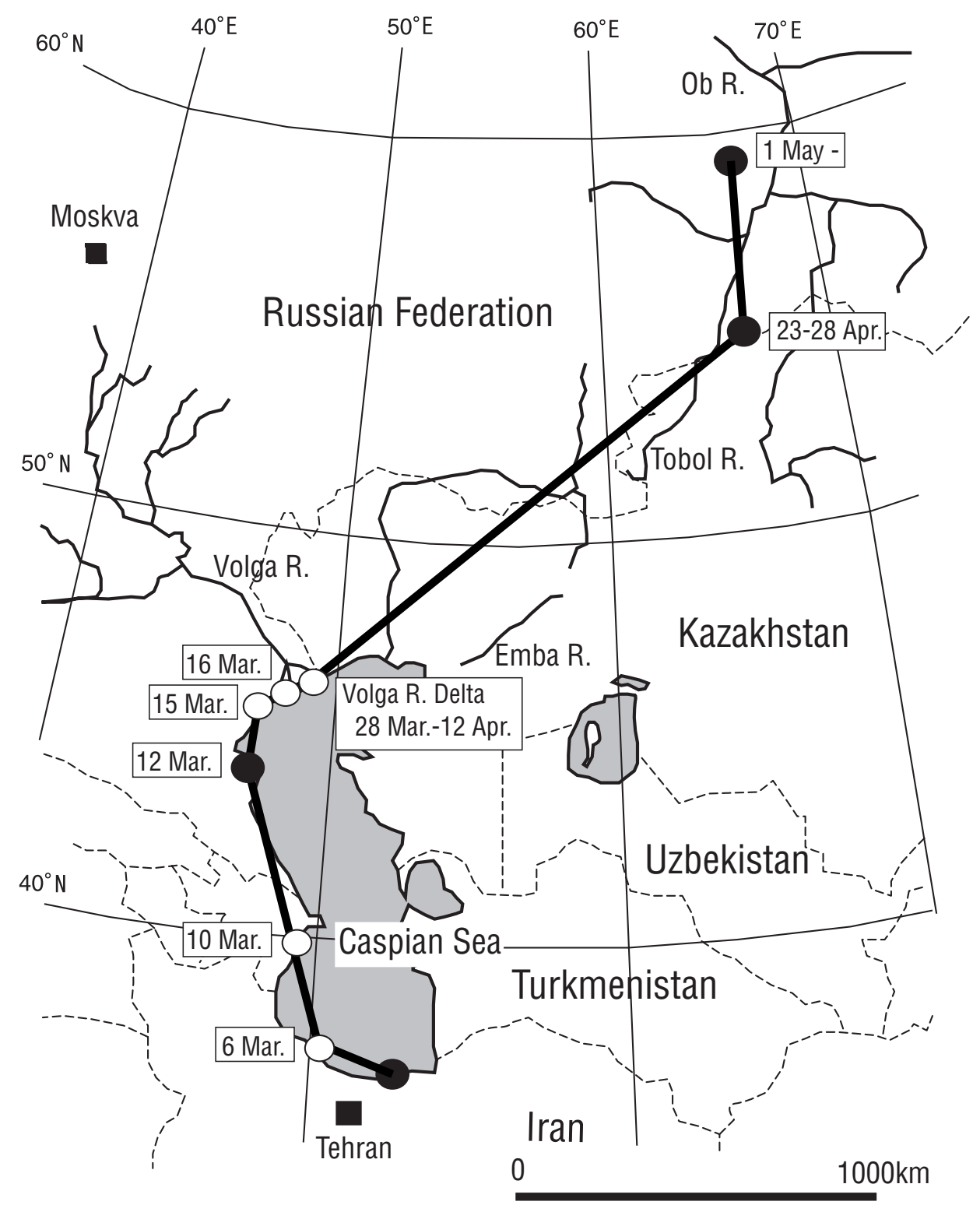

Figure 1. Migration route and important stopover sites of a Siberian Crane satellite tracked during spring of 1996. The Siberian Crane migrated from its winter site in Iran on the southern tip of the Caspian Sea, to its breeding grounds in western Siberia. Black circles show the locations with high-quality data (accuracy of $<1000 \mathrm{~m}$ ), and white circles show the locations with lower quality data (> $1000 \mathrm{~m})$. 
A.G.S. and Y.M. carried out an aerial survey of this summer range in mid-June 1996. They found one more pair of Siberian Cranes near the territory of the satellite-tracked crane. This area is rich in lakes and bogs with hummock ridge, hummock ridge-hollow, hummock ridge-lacustrine, swampy, and grass-swampy habitats. Black Stork Ciconia nigra, White-tailed Eagle Haliaeetus albicilla, Imperial Eagle Aquila heliaca, and presumably Slender-billed Curlew Numenius tenuirostris breed in this area (All Russian Research Institute for Nature Protection pers. comm.).

This breeding location is approximately $650 \mathrm{~km}$ directly south of the Kunovat River basin, the breeding area of the birds known to winter at Keoladeo National Park in India. The migration routes of Siberian Cranes that winter in Iran and India overlapped from Armizon, Russia into north-west Kazakhstan (Archibald 1994).

\section{Conservation issues}

Historically the breeding range of the western population of Siberian Crane perhaps extended from south of the Ural Mountains, to north of the Kunovat River basin, and east to Tyumen, occupying the many marshes in the region. The wintering areas were also perhaps more extensive than the two known sites in India and Iran. Sauey (1985) provides many details of the historical records of Siberian Crane, but many of these sightings date back to the nineteenth century.

The western population is on the verge of extinction, and the subgroup that winters in India is biologically extinct. To conserve the tiny western population, hunter education and habitat protection are essential. The tracking of this Siberian Crane's spring migration north from its wintering grounds at Ferey-dunkinar revealed important staging/stopover sites that should be protected, to provide safe passage during migration.

This satellite tracking effort confirmed for the first time the exact breeding grounds of the small group of Siberian Cranes that winters in Iran. It also established the importance of wetlands east of the Ural Mountains and west of the town of Uvat (breeding site), as well as on the Volga delta (resting site). This western flyway of waterbirds, all the way from the breeding grounds north of the Arctic Circle to the several wintering sites from the Middle East to the Indian subcontinent, is well known and important. One of the principal threats to the western population of Siberian Crane seems to be hunting (Meine and Archibald 1996), and there is likely to be considerable hunting pressure all along this flyway. To ensure the continued survival of this Critically Endangered species in this flyway, it is imperative to address all the threats that face these rare birds.

\section{Acknowledgements}

We thank D. Hykle (Convention on Migratory Species), D. Ferguson (USFWS), B. Mashallah, M. Ashtiani, M. Rouzbehani, and other authorities in Iran who made it possible to capture and deploy a transmitter on a wild Siberian Crane in Iran. Financial and transportation support was provided by the National Wildlife Federation, NEC Corporation, Amoco Corporation and Lufthansa German Air- 
lines. The PTT for the project was donated by NTT. The captive bird used as decoy was donated by the International Crane Foundation.

\section{References}

Archibald, G. (1994) The fading call of the Siberian Crane. Nat. Geogr. 185(5): 124-136. Argos (1996) User manual. Toulouse, France: Service Argos.

BirdLife International (2000) Threatened birds of the world. Barcelona, Spain and Cambridge, U.K.: Lynx Edicions and BirdLife International.

Center for Conservation Research and Technology (CCRT) (1999) Resource managers' technical review: advanced technologies for conservation of biodiversity, habitats and ecosystems. Baltimore, MD, and Boise, ID: Center for Conservation Research and Technology.

Cramp, S., ed. (1980) Handbook of the birds of Europe the Middle East and North Africa, 2. Oxford: Oxford University Press.

Higuchi, H., Ozaki, K., Fujita, G., Soma, M., Kanmuri, N. and Ueta, M. (1992) Satellite tracking of the migration routes of cranes from southern Japan. Strix 11: 1-20.

Higuchi, H., Nagendran, M., Sorokin, A. G. and Ueta, M. (1994) Satellite tracking of Common Cranes Grus grus migrating north from Keoladeo National Park, India. Pp. 26-31 in H. Higuchi and J. Minton, eds. The future of cranes and wetlands. Tokyo, Japan: Wild Bird Society of Japan.

Higuchi, H., Ozaki, K., Fujita, G., Minton, J., Ueta, M., Soma, M. and Mita, N. (1996) Satellite tracking of White-naped Crane migration and the importance of the Korean Demilitarized Zone. Conserv. Biol. 10: 806-812.

Kanai, Y., Kondoh, A. and Higuchi, H. (1994) Analysis of crane habitat using satellite images. Pp. $72-85$ in H. Higuchi and J. Minton, eds. The future of cranes and wetlands. Tokyo, Japan: Wild Bird Society of Japan.

Kanai, Y., Ueta, M., Germogenov, N., Nagendran, M., Mita, M. and Higuchi, H. (2002) Migration routes and important resting areas of Siberian cranes (Grus leucogeranus) between northeastern Siberia and China as revealed by satellite tracking. Biol. Conserv. 106: $339-346$.

Meine, C. D. and Archibald, G. W. (1996) The cranes: status survey and conservation action plan. Gland, Switzerland and Cambridge, U.K.: IUCN.

Nagendran, M. (1995) Behavioral ontogeny and release of costume-reared Siberian and Sandhill Crane chicks. Ph.D. thesis. North Dakota State University, Fargo, ND.

Nagendran, M., Higuchi, H. and Sorokin, A. G. (1994) A harnessing technique to deploy transmitters on cranes. Pp. 57-60 in H. Higuchi and J. Minton, eds. The future of cranes and wetlands. Tokyo, Japan: Wild Bird Society of Japan.

Sauey, R. T. (1985) The range, status, and winter ecology of the Siberian Crane Grus leucogeranus. Ph.D. dissertation. Cornell University, Ithaca, NY.

Ueta, M., Sato, F., Nakagawa, H. and Mita, N. (2000) Migration routes and differences of migration schedule between adult and young Steller's Sea Eagles Haliaeetus pelagicus. Ibis 142: 35-39.

Ueta, M., Melville, D. S., Wang, Y., Ozaki, K., Kanai, Y., Leader, P. J., Wang, C. and Kuo, C. (2002) Discovery of the breeding sites and migration routes of Black-faced Spoonbills Platalea minor. Ibis 144: 340-343.

YUTAKA KANAI and MUTSUYUKI UETA

Research Center, Wild Bird Society of Japan, 2-35-2 Minamidaira, Hino, Tokyo, 191-0041, Japan. E-mail: research@wing-wbsj.or.jp 
MEENAKSHI NAGENDRAN

Dept. of Environmental Studies, California State University-Sacramento, Sacramento, CA 958196001, U.S.A.

YURI MARKIN

Oka State Biosphere Nature Reserve, Brykin Bor, Spassky Region, Ryazanskaya Oblast, 391072 P.O. Lakash, Russia.

JUHANI RINNE

P.O.Box 503, SF-00101, Helsinki, Finland.

ALEXANDER. G. SOROKIN

All Russian Research Institute for Nature Protection, Znamenskoye - Sadki, Moscow, M-628, 113628, Russia.

HIROYOSHI HIGUCHI

Laboratory of Biodiversity Science, The University of Tokyo, 1-1-1 Yayoi, Bunkyo-ku, Tokyo 1138657, Japan.

GEORGE ARCHIBALD

International Crane Foundation, E-11376 Shady Lane Road, Baraboo, Wisconsin 53913, U.S.A.

Received 1 May 2001; revision accepted 16 July 2002 